\title{
Analysis of Saccharomyces cerevisiae proteins induced by peroxide and superoxide stress
}

\author{
Derek J. Jamieson, Stuart L. Rivers and Duncan W. S. Stephen
}

Author for correspondence: Derek J. Jamieson. Tel: +44 382 60111, ext. 3519. Fax : +44 38269993.

Biomedical Research Centre, Ninewells Hospital and Medical School, University of Dundee, Dundee DD1 9SY, UK

\begin{abstract}
Exponentially growing Saccharomyces cerevisiae cells are more sensitive to oxidants such as hydrogen peroxide and superoxides than stationary phase cells. Using disruption mutations in the genes encoding the two S. cerevisiae superoxide dismutases, we show that the principal mechanism of toxicity of redox-cycling compounds, such as menadione and plumbagin, is via the production of superoxide anions. Using two-dimensional polyacrylamide gel electrophoresis we have compared the pattern of protein expression in cells labelled with L-[35S]methionine and stressed with either $\mathrm{H}_{2} \mathrm{O}_{2}$ or menadione. Three groups of proteins were evident: those whose levels are elevated by both $\mathrm{H}_{2} \mathrm{O}_{2}$ and menadione, and those specifically induced by either $\mathrm{H}_{2} \mathrm{O}_{2}$ or menadione. Experiments with promoter fusions demonstrated that one of the heat inducible forms of HSP70 (SSA1) was inducible with $\mathrm{H}_{2} \mathrm{O}_{2}$. Furthermore, induction of the yeast $\mathrm{H}_{2} \mathrm{O}_{2}$-responsive TRX2 promoter by menadione required the metabolism of menadione.
\end{abstract}

Keywords: yeast, oxidative stress, Saccharomyces cerevisiae

\section{INTRODUCTION}

All aerobically growing micro-organisms encounter reactive oxygen species (ROS), including the superoxide anion $\left(\mathrm{O}_{2}^{-}\right), \mathrm{H}_{2} \mathrm{O}_{2}$ and the hydroxyl radical. ROS can be generated as a consequence of normal cellular metabolic processes such as respiration or the $\beta$-oxidation of fatty acids. Alternatively, ROS can be produced through the metabolism of foreign chemicals or by the host immune system. Indeed, the microbiocidal effect of ROS is central to the destruction of potential pathogens (Baggiolini \& Thelen, 1991). The toxicity of ROS is due to their ability to damage a large number of cellular constituents. For example, ROS produce double-stranded breaks and apurinic and apyrimidinic bases in DNA (Storz et al., 1987). Damage to lipids by ROS arises from the formation of lipid peroxides, and, in proteins, amino acid side chains can become oxidized (Wolff et al., 1986). As a result of the harmful nature of ROS, many aerobically growing organisms possess strategies for protection against oxidative stress, which involve the synthesis and activation of protective enzymes or molecules.

Considerable attention has been focused on the adaptive oxidative stress responses of bacteria, principally Escherichia coli and Salmonella typhimurium, although adaptive oxidative stress responses have been demonstrated in

Abbreviations: ROS, reactive oxygen species; SOD, superoxide dismutase.
Bacillus subtilis and Streptomyces coelicolor (Dowds et al., 1987; Lee et al., 1993). Treatment of E. coli with $\mathrm{H}_{2} \mathrm{O}_{2}$ results in the synthesis of about 30 proteins and causes the activation of a transcription factor (OxyR) which acts on the promoters of nine genes whose products are required for protection against oxidative stress (Storz et al., 1990). There is also an additional stress response in E. coli to the presence of superoxide anions (Demple \& AmabileCuevas, 1991) which is regulated by the soxR and soxS gene products and results in the induction of a number of genes including those encoding superoxide dismutase, glucose-6-phosphate dehydrogenase and the DNA repair enzyme exonuclease IV (reviewed by Demple, 1991). Despite the distinct regulatory nature of these adaptive stress responses there is some overlap between them, and several proteins are induced by both stress responses (Greenberg \& Demple, 1989). Some of the overlap can be explained by the production of $\mathrm{H}_{2} \mathrm{O}_{2}$ from $\mathrm{O}_{2}^{-}$by both non-enzymic and enzymic mechanisms (Halliwell \& Gutteridge, 1984).

The yeast Saccharomyces cerevisiae represents an ideal organism in which to study the regulation of gene expression in response to oxidative stress. This organism, unlike higher eukaryotes, is readily amenable to both genetic analysis and molecular biological techniques. Recent work has shown that $S$. cerevisiae possesses distinct inducible protective oxidative stress responses to both peroxides and superoxides (Jamieson, 1992; Collinson \& 
Dawes, 1992; Flattery-O'Brien et al., 1993). This study demonstrates that the toxic action of the redox cycling compounds menadione and plumbagin is due to the production of superoxide anions. The profiles of proteins induced in response to both $\mathrm{H}_{2} \mathrm{O}_{2}$ and menadione have been compared by two-dimensional polyacrylamide gel electrophoresis, which shows that there are significant overlaps between the two stress responses. We have used gene fusions to a number of yeast promoters to demonstrate that they are regulated at the level of transcription by $\mathrm{H}_{2} \mathrm{O}_{2}$.

\section{METHODS}

Yeast strains and techniques. Standard yeast methods and growth media were as described by Sherman et al. (1982). The yeast strains and plasmids used are described in Table 1. Disruption of the SOD1 and SOD2 genes was by the method of Rothstein (1983). Strains DJY118 and DJY119 were constructed by transformation, using lithium acetate (Ito et al., 1983), with either a linearized EcoRI/SalI fragment of pDJ51, containing the sod1::UR $A 3$ gene disruption, or an EcoRI/ HindIII fragment of $\mathrm{pDJ} 50$, containing the sod2:: TRP1 gene disruption. To confirm that the SOD1 and SOD2 genes were disrupted, polymerase chain reactions (PCR) were performed on genomic DNA isolated from $\mathrm{Ura}^{+}$and $\mathrm{Trp}^{+}$transformants, respectively, using the primers described below. In all cases only the fragments corresponding to the disrupted genes were observed. The presence or absence of either the MnSOD or $\mathrm{Cu} / \mathrm{ZnSOD}$ activity was checked by enzyme assays as described by McCord \& Fridovich (1969). $\beta$-Galactosidase assays were performed as described by Rose et al. (1990). Menadione (bisulphite salt) and plumbagin were obtained from Sigma. $\mathrm{H}_{2} \mathrm{O}_{2}(30 \%$, w/v) solution was obtained from $\mathrm{BDH}$. Media

Table 1. Strains and plasmids

\begin{tabular}{|c|c|c|}
\hline $\begin{array}{l}\text { Strain or } \\
\text { plasmid }\end{array}$ & Relevant genotype & $\begin{array}{l}\text { Source or } \\
\text { reference }\end{array}$ \\
\hline \multicolumn{3}{|l|}{ S. cerevisiae } \\
\hline S150-2B & 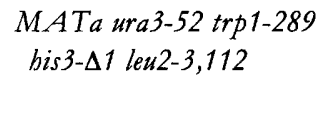 & $\begin{array}{l}\text { J. Beggs, ICMB, } \\
\text { University of } \\
\text { Edinburgh, UK }\end{array}$ \\
\hline DJY118 & 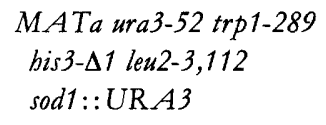 & $\begin{array}{l}\text { Derived from } \\
\text { S150-2B }\end{array}$ \\
\hline DJY119 & $\begin{array}{l}\text { MATa ura3-52 trp1-289 } \\
\text { bis3- } 1 \text { l leu2-3,112 } \\
\text { sod2:: TRP1 }\end{array}$ & $\begin{array}{l}\text { Derived from } \\
\text { S150-2B }\end{array}$ \\
\hline \multicolumn{3}{|l|}{ Plasmids } \\
\hline pDJ50 & sod2:: TRP1 & This study \\
\hline pDJ51 & $\operatorname{sod} 1:: U R A 3$ & This study \\
\hline pYDJ59 & SOD2::lacZ UR $A 3$ & This study \\
\hline pYDJ60 & SOD1:: lacZ UR A3 & This study \\
\hline pYDJ61 & $C T A 1:: \operatorname{lac} Z \cup \mathrm{R} A 3$ & This study \\
\hline pYDJ64 & CTT1::lacZ UR A3 & This study \\
\hline pYTRX2 & $T R X 2:: \operatorname{lac} Z \cup R A 3$ & $\begin{array}{l}\text { Kuge \& Jones } \\
\text { (1994) }\end{array}$ \\
\hline pZJHSE2-137 & SS $A 1:: \operatorname{lac} Z U R A 3$ & $\begin{array}{l}\text { Slater \& Craig } \\
\text { (1987) }\end{array}$ \\
\hline
\end{tabular}

components were obtained from Difco. All other chemicals were of analytical grade.

Plasmid construction. The sod 1 insertion mutation was constructed by amplifying a $0.558 \mathrm{~kb}$ fragment of the SOD 1 gene, which includes most of the coding sequence, from genomic DNA using the following oligonucleotide primers in a PCR reaction: 5'-GCCGGTGTCTCTGGTG-3' and 5'-GGCCGCCCCGGCACA-3'. The amplified fragment (from nucleotide +33 to +591 ) was cloned into pT7-Blue $\mathrm{T}$ (Novagen) then excised as an EcoRI-SalI fragment and ligated to the large EcoRI-SalI fragment of pBR322. The $1.116 \mathrm{~kb}$ HindIII fragment from YEP24, containing the UR $A 3$ gene, was inserted into the HindIII site in the SOD1 coding sequence, creating plasmid pDJ51. To create a deletion mutation in the SOD2 gene the following oligonucleotide primers were used in a PCR reaction to amplify a $0.941 \mathrm{~kb}$ fragment containing the majority of the SOD2 coding sequence from genomic DNA: 5'-TGTCATTGCTCTCCACCACAGC-3' and 5'-GGTTCTCTGCCTGGTGGTGAG-3'. The amplified fragment (from nucleotide +46 to +987 ) was subsequently cloned into pT7-

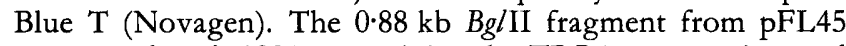
(Bonneaud et al., 1991), containing the TRP1 gene was inserted between the two $B g / I I$ sites internal to the SOD 2 gene, creating $\mathrm{pDJ} 50$. The positions of all PCR primers are given relative to the ATG codon.

SOD1, SOD2, CTA1 and CTT1:: lacZ gene fusions. To construct the SOD1, SOD2, CTA1 and CTT1::lacZ gene fusions the following oligonucleotide primer pairs, having either $X b o \mathrm{I}$ or $B a m$ HI sites at the $5^{\prime}$ end, were used to amplify the promoter regions of these genes by PCR from genomic DNA. SOD1: $5^{\prime}-$ CCGCTCGAGCTGCGACTCATCCATGTG-3', 5'-CGCGGATCCACTGCGACTGCTTGAAC-3'; SOD2: 5'-ACGCTCGAGCGACGCCACCATCCTATC-3', 5'-CGGGATCCGCGAACATCCTGGTAC-3'; CT $A 1$ : 5'-CCGCTCCAGGAAT'TCTTAGAAGGTGAAGAA-3', 5'-CGCGGATCCAATTTCGACATCTTCTAGGGT-3'; CTT1: 5'-CCGCTCCAGGGTTGCAAGTCCGAGAAC-3', 5'-CGCGGATCCACGTTCAT'T'TGTGAAGCTGA-3'.

The amplified DNA fragments contained the following regions of promoter sequence: SOD1 from -412 to +20 ; SOD2 from -551 to $+11 ; C T A 1$ from -820 to $+11 ; C T T 1$ from -588 to +14 . The amplified promoter fragments were digested with $X b o \mathrm{I}$ and $B a m \mathrm{HI}$ and inserted into the vector pLG670-Z (Guarente, 1983). Insertion of DNA into the XhoI-BamHI sites fuses the promoter fragment to the $E$. coli lac $Z$ gene.

Menadione and $\mathrm{H}_{2} \mathrm{O}_{2}$ adaptation experiments. To determine the degree of protection against cell killing afforded by menadione and $\mathrm{H}_{2} \mathrm{O}_{2}$ pretreatment, exponential phase cultures of strain S150-2B or its isogenic sod1 or sod2 derivatives (DJY118 and DJY119, respectively) were grown aerobically in YPD (Sherman et al., 1982) at $30^{\circ} \mathrm{C}$ in the presence or absence of either $\mathrm{H}_{2} \mathrm{O}_{2}\left(0^{-4} \mathrm{mM}\right)$ or menadione $(1 \mathrm{mM})$ for $1 \mathrm{~h}$. Cells were collected by centrifugation and washed once in distilled water prior to resuspension in an equal volume of fresh pre-warmed YPD medium. Aliquots $(1 \mathrm{ml})$ of these cells were then incubated for $1 \mathrm{~h}$ at $30^{\circ} \mathrm{C}$ with increasing levels of either menadione, plumbagin or $\mathrm{H}_{2} \mathrm{O}_{2}$, after which time cells were washed once in distilled water, plated out at appropriate dilutions on YPD plates and incubated at $30^{\circ} \mathrm{C}$.

Two-dimensional polyacrylamide-gel electrophoresis. Cellular proteins were labelled prior to, or during exposure to, levels of oxidants sufficient to induce an adaptive response, either $\mathrm{H}_{2} \mathrm{O}_{2}(0.4 \mathrm{mM})$ or menadione $(1 \mathrm{mM})$ by adding $\mathrm{L}-$ $\left[{ }^{35} \mathrm{~S}\right]$ methionine $(1.85 \mathrm{MBq}, 50 \mu \mathrm{Ci}$; Amersham) to the growth 
medium (SD; Sherman et al., 1982). Labelling was continued for $15 \mathrm{~min}$, then the cells were pelleted and washed twice in $1 \mathrm{ml}$ lysis buffer $(50 \mathrm{mM}$ Tris/HCl, $\mathrm{pH} 8.0 ; 150 \mathrm{mM} \mathrm{NaCl} ; 1 \%$, $\mathrm{v} / \mathrm{v}, \mathrm{NP40}$ ). Cell pellets were resuspended in $100 \mu \mathrm{l}$ lysis buffer to which approximately $100 \mu \mathrm{l}$ glass beads were added (diameter $0.4 \mu \mathrm{m} ; \mathrm{BDH})$. Cells were broken by vortexing for four $1 \mathrm{~min}$ cycles with $1 \mathrm{~min}$ on ice in between. After centrifugation to remove cell debris, $100 \mu$ lof first dimension sample buffer $(9 \mathrm{M}$ urea; $2 \% \mathrm{NP} 40 ; 5 \%, \mathrm{v} / \mathrm{v}, \beta$-mercaptoethanol; $1.6 \%, \mathrm{v} / \mathrm{v}$, ampholyte $\mathrm{pH} 5-7 ; 0.4 \%$ ampholyte $\mathrm{pH} 3-10$ ) was added to the extract. Equivalent amounts of radioactivity from each extract were loaded onto first dimension gels containing $9 \cdot 2 \mathrm{M}$ urea, $4 \%$ (v/v) acrylamide $2 \%$ NP40 1.6\% ampholyte $\mathrm{pH} 5-7,0.4 \%$ ampholyte $\mathrm{pH} 3-10$, and subjected to electrophoresis at $750 \mathrm{~V}$. Second dimension gels were SDS-PAGE gels ( $12 \%$ acrylamide) (Laemmli, 1970).

\section{RESULTS AND DISCUSSION}

\section{Effect of growth phase on $\mathrm{H}_{2} \mathrm{O}_{2}$ and plumbagin sensitivity}

It has been shown previously that $S$. cerevisiae cells from stationary phase cultures are considerably more resistant to oxidants than exponentially growing cultures (Jamieson, 1992). Further experiments revealed some variability in the resistance of different batch cultures towards oxidants. To characterize this in more detail we determined the resistance of cells to oxidants at various points in the growth of batch cultures. The results (Fig. 1) show that as cells in batch culture approach stationary phase, possibly at the point of diauxic shift, they become increasingly mote resistant to both $\mathrm{H}_{2} \mathrm{O}_{2}$ and plumbagin. In all subsequent experiments we utilized cultures that were grown aerobically in YPD or SD medium and were in the early exponential phase of growth.

\section{The toxicity of redox cyclers towards $S$. cerevisiae is due to the production of superoxide anions}

It has been demonstrated previously that $S$. cerevisiae is sensitive both to $\mathrm{H}_{2} \mathrm{O}_{2}$ and to superoxide-generating agents such as menadione and plumbagin (Jamieson, 1992; Collinson \& Dawes, 1992; Flattery-O'Brien et al., 1993). To establish that cells were sensitive to superoxidegenerating agents as a consequence of the production of superoxide anions, and not through some other means, we constructed a series of isogenic yeast strains that were disrupted in either the SOD1 or the SOD2 genes (encoding the $\mathrm{Cu} / \mathrm{ZnSOD}$ and mitochondrial MnSOD respectively) (Bermingham-McDonogh et al., 1988; Van Loon et al., 1986). Strains DJY118 ( $\Delta$ sod1::UR $A 3$ ) and DJY119 ( $\Delta$ sod2: : TRP1) were exposed to various concentrations of oxidants for $1 \mathrm{~h}$ and cell viability measured. The results (Fig. 2a) show that the $\Delta$ sod1 mutant is 100 -fold more sensitive to plumbagin than its isogenic parent. By contrast, the sensitivity of the $\Delta s o d 2$ strain to plumbagin is indistinguishable from that of the wild-type strain, S1502B. The sensitivity of the $\Delta s o d 1$ and $\Delta s o d 2$ strains to $\mathrm{H}_{2} \mathrm{O}_{2}$ remains unchanged (Fig. $2 \mathrm{~b}$ ). These results provide strong evidence that the $\mathrm{Cu} / \mathrm{ZnSOD}$ is the principal superoxidedismutating activity under these growth conditions and that the toxic action of redox cyclers such as menadione

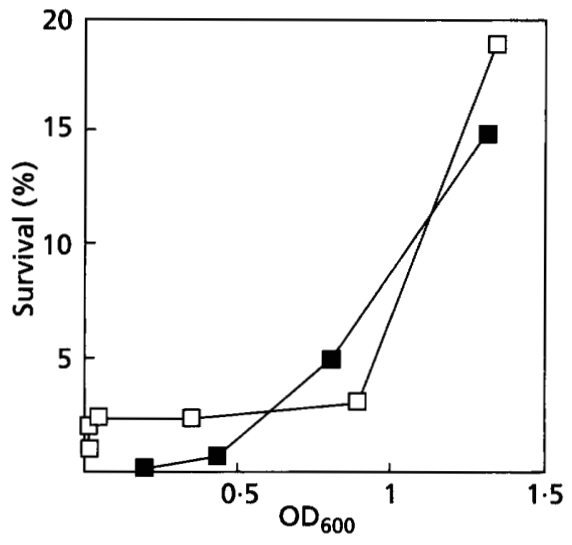

Fig. 1. Effect of growth in batch culture on oxidant sensitivity of yeast cells. Aliquots $(1 \mathrm{ml})$ of batch cultures of S150-2B growing aerobically at $30^{\circ} \mathrm{C}$ in YPD medium were withdrawn at various points in the growth cycle and exposed for $1 \mathrm{~h}$ to either $2.45 \mathrm{mM} \mathrm{H} \mathrm{O}_{2}(\square)$ or $70 \mu \mathrm{M}$ plumbagin $(\square)$. Samples were then diluted and plated on to YPD plates to measure cell viability. Data are from a representative experiment.
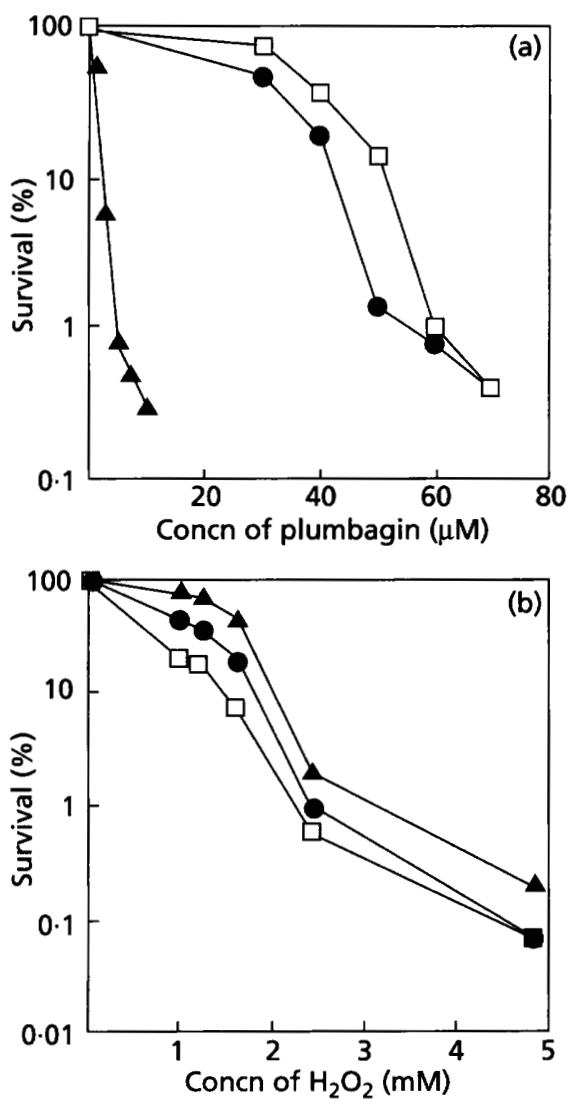

Fig. 2. Sensitivity of SOD null mutants to redox-cycling compounds. Aliquots $(1 \mathrm{ml})$ of aerobically grown, exponential phase cultures of S150-2B ( $\square$ ), DJY118 ( $\Delta$ sod1) ( $A$ ) and DJY119 ( $\Delta$ sod2) (O) were exposed to increasing concentrations of plumbagin (a) or $\mathrm{H}_{2} \mathrm{O}_{2}$ (b) for $1 \mathrm{~h}$ at $30^{\circ} \mathrm{C}$. Samples were then diluted and plated onto YPD plates to measure cell viability. Data are from a representative experiment. 

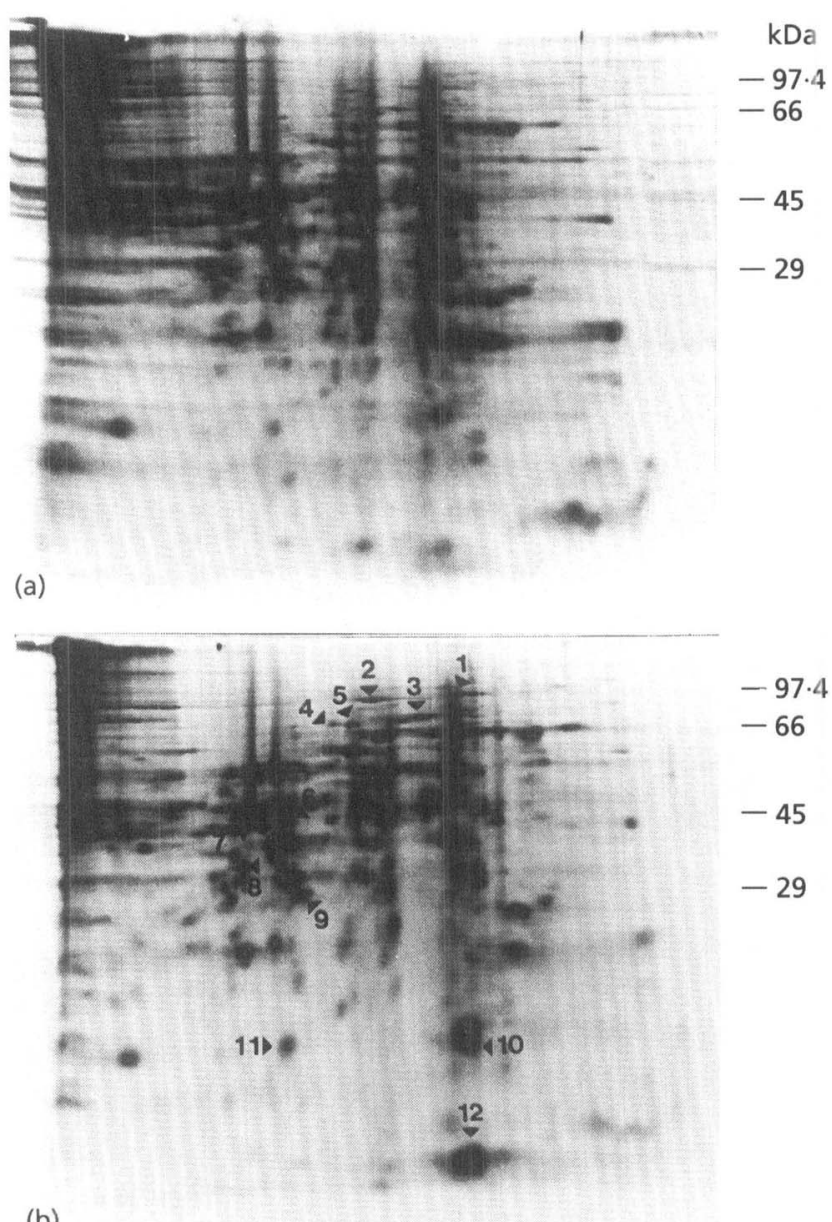

(b)

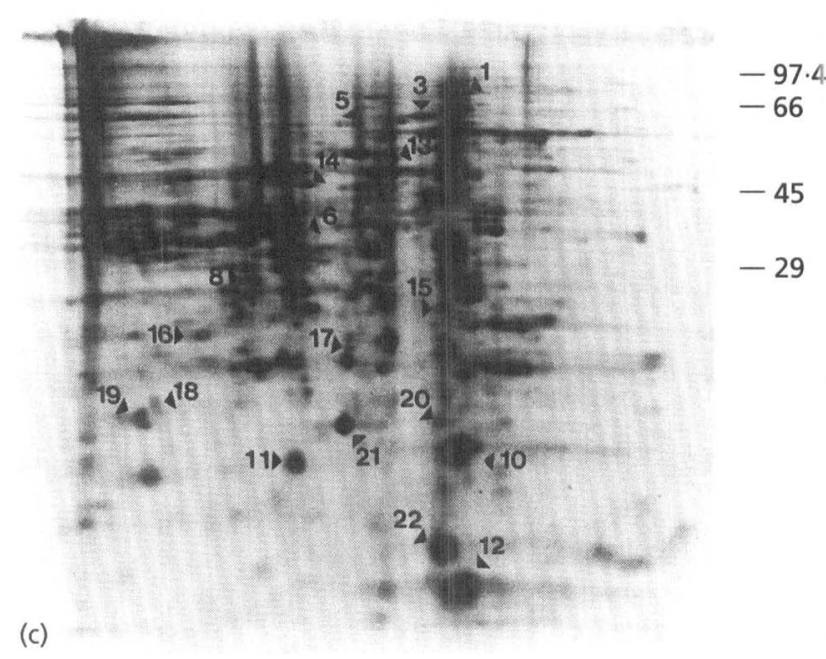

Fig. 3. Two-dimensional gel analysis of protein extracts from yeast cells exposed to $0.4 \mathrm{mM} \mathrm{H}_{2} \mathrm{O}_{2}$ (b) or $1 \mathrm{mM}$ menadione (c), and from control cells (a). Cells were exposed to the oxidants for $30 \mathrm{~min}$ and then labelled with $\left.\mathrm{L}-{ }^{35} \mathrm{~S}\right]$ methionine for a further $15 \mathrm{~min}$. Extracts were prepared as described in Methods. An equal amount of radioactivity was loaded onto each gel. Induced proteins are labelled by arrows and numbered. and plumbagin is due to superoxide anion production. The role of the mitochondrially located MnSOD appears to be restricted to protecting cells against superoxide anions produced as by-products of respiration (Guidot $e t$ $a l ., 1993)$. The induction of the adaptive oxidative stress responses was examined in the $\Delta s o d$ mutants. The peroxide and superoxide adaptive stress responses were both functional in the SOD2 deletion mutant (data not shown). In the SOD1 deletion mutant, the peroxide stress response was normal; however, this strain was so sensitive to superoxide anion generators that no adaptive stress response could be measured by cell viability counts (data not shown).

\section{Two-dimensional gel analysis of proteins induced by oxidants}

To determine the number of proteins induced by both types of oxidative stress and the relationship between the two responses, labelled extracts from cells which had been exposed to oxidants were prepared. Cultures of exponentially growing yeast were exposed to oxidants for $30 \mathrm{~min}$ immediately prior to labelling proteins with $\left[{ }^{35} \mathrm{~S}\right]$ methionine; incubation with $\left[{ }^{35} \mathrm{~S}\right]$ methionine was carried out for $15 \mathrm{~min}$ at $30^{\circ} \mathrm{C}$ and the labelled proteins were separated using SDS-PAGE (data not shown). To improve the resolution of individual proteins, labelled extracts were subjected to two-dimensional gel electrophoresis as described in Methods. The results (Fig. $3 \mathrm{a}, \mathrm{b}, \mathrm{c}$ ) show the pattern of major proteins induced by the two stresses. Electrophoresis on two-dimensional gels allowed the resolution of 12 proteins whose levels are elevated in response to $\mathrm{H}_{2} \mathrm{O}_{2}$ and 18 proteins whose levels are increased by treatment with menadione. Analysis of the gels suggests that these proteins can be grouped, based on their pattern of expression: those induced solely by either $\mathrm{H}_{2} \mathrm{O}_{2}$ or menadione; and those induced by both oxidants (Table 2). Several of the proteins induced by both of the oxidants appear to correspond to previously identified heat-shock proteins (Petko \& Lindquist, 1986) (for example, protein 10 corresponds to HSP26). This supports our previous finding that induction of the heatshock response can provide cross-protection against both $\mathrm{H}_{2} \mathrm{O}_{2}$ and superoxides, raising the possibility that these heat-shock proteins may also protect against oxidative stress. Recently it has been demonstrated that HSP26 is also induced by osmotic stress (Varela et al., 1992).

\section{Regulation of gene expression by oxidant stress}

Since some of the oxidant-induced proteins appear to correspond to heat-shock proteins, we looked at the expression of the yeast heat-shock gene $S S A 1$, in the presence of oxidants. We utilized a gene fusion consisting of the $S S A 1$ promoter fused to the E. coli lac $Z$ gene, which contained the sequences necessary for mediating the regulation of this gene in response to heat shock (Slater \& Craig, 1987). Exponential phase cultures of strains carrying this gene fusion were exposed to levels of oxidants that elicit an adaptive response for $1 \mathrm{~h}$ and assayed for $\beta$-galactosidase activity. The results (Table 3 ) 
Table 2. Proteins induced by exposure to $\mathrm{H}_{2} \mathrm{O}_{2}$ or menadione

Protein numbers correspond to those used in Fig. 3. Only those proteins that reproducibly showed elevated expression upon oxidant exposure are described.

\begin{tabular}{|c|c|c|c|}
\hline \multicolumn{2}{|c|}{$\mathbf{H}_{2} \mathbf{O}_{2}$} & \multicolumn{2}{|c|}{ Menadione } \\
\hline Protein & $\begin{array}{l}\text { Approx. mol. } \\
\text { mass (kDa) }\end{array}$ & Protein & $\begin{array}{l}\text { Approx. mol. } \\
\text { mass (kDa) }\end{array}$ \\
\hline 1 & 156 & 1 & 156 \\
\hline 2 & $97 \cdot 4$ & 3 & $77 \cdot 8$ \\
\hline 3 & $77 \cdot 8$ & 5 & $72 \cdot 9$ \\
\hline 4 & $72 \cdot 9$ & 13 & $61 \cdot 3$ \\
\hline 5 & $72 \cdot 9$ & 14 & 53 \\
\hline 6 & $41 \cdot 7$ & 6 & $41 \cdot 7$ \\
\hline 7 & $40 \cdot 4$ & 8 & 36 \\
\hline 8 & 36 & 15 & $30 \cdot 4$ \\
\hline 9 & $32 \cdot 3$ & 16 & $28 \cdot 4$ \\
\hline 10 (HSP26) & $25 \cdot 7$ & 17 & $27 \cdot 9$ \\
\hline 11 & 25 & 18 & $26 \cdot 2$ \\
\hline \multirow[t]{7}{*}{12 (HSP12) } & 14 & 19 & $25 \cdot 7$ \\
\hline & & 20 & $25 \cdot 7$ \\
\hline & & 10 (HSP26) & $25 \cdot 7$ \\
\hline & & 21 & $25 \cdot 5$ \\
\hline & & 11 & 25 \\
\hline & & 22 & $21 \cdot 7$ \\
\hline & & 12 (HSP12) & 14 \\
\hline
\end{tabular}

Table 3. Effect of oxidants on transcription of the SSA1, TRX2, SOD1, SOD2, CTA1, CTT1 genes

Cultures of S150-2B transformed with the gene fusion plasmids (Table 1) were grown aerobically at $30^{\circ} \mathrm{C}$ in $\mathrm{SD}$ medium to early exponential phase (approximate $\mathrm{OD}_{600}=0 \cdot 1$ ). Cultures were then exposed to either $\mathrm{H}_{2} \mathrm{O}_{2}(0 \cdot 4 \mathrm{mM})$ or menadione $(1 \mathrm{mM})$ for $1 \mathrm{~h}$. Cells were harvested and extracts prepared and assayed as described in Methods. Values presented are the means of duplicate assays \pm range.

\begin{tabular}{|c|c|c|c|}
\hline \multirow[t]{2}{*}{ Gene fusion } & \multicolumn{3}{|c|}{$\begin{array}{l}\text { Specific activity } \\
\text { [nmol ONPG hydrolysed } \mathrm{min}^{-1} \\
\left.(\mathrm{mg} \text { protein })^{-1}\right]\end{array}$} \\
\hline & No stress & $+\mathrm{H}_{2} \mathrm{O}_{2}$ & + Menadione \\
\hline$S S A 1:: \operatorname{lac} Z$ & $4.85 \pm 0.05$ & $68 \cdot 6 \pm 1 \cdot 6$ & $5 \cdot 45 \pm 0 \cdot 12$ \\
\hline TRX2::lacZ & $12.5 \pm 0.07$ & $286 \pm 8 \cdot 6$ & $14 \cdot 5 \pm 0 \cdot 35$ \\
\hline SOD1::lacZ & $1.673 \pm 0.07$ & $1 \cdot 371 \pm 0 \cdot 01$ & $1 \cdot 838 \pm 0 \cdot 07$ \\
\hline SOD2::lacZ & $0.299 \pm 0.03$ & $0.473 \pm 0.002$ & $0.368 \pm 0.03$ \\
\hline$C T A 1:: \operatorname{lac} Z$ & $0.159 \pm 0.02$ & $0.196 \pm 0.01$ & $0 \cdot 126 \pm 0.01$ \\
\hline CTT1::lacZ & $0.082 \pm 0.006$ & $0.178 \pm 0.02$ & $0.088 \pm 0.02$ \\
\hline
\end{tabular}

demonstrate that this portion of the $S S A 1$ promoter is capable of increasing expression in response to $\mathrm{H}_{2} \mathrm{O}_{2}$ in addition to heat shock, showing that the levels of at least one of the HSP70 isoforms of yeast is elevated by oxidative stress. Transcriptional regulation of the $S S A 1$ gene is similar to that of the yeast $T R X 2$ gene (encoding one of the two yeast thioredoxins), which has also recently been shown to be oxidant-inducible (Table 3) (Kuge \& Jones, 1994).

We also constructed lacZ gene fusions to the CTT1, $C T A 1, S O D 1$ and SOD 2 promoters, encoding the two yeast catalases and the mitochondrial MnSOD and cytosolic $\mathrm{Cu} / \mathrm{ZnSOD}$ respectively, since these enzymes represent important defence systems against oxidants. Transformants of S150-2B containing the gene fusions were grown aerobically to early exponential phase and then treated for $1 \mathrm{~h}$ with either $\mathrm{H}_{2} \mathrm{O}_{2}$ or menadione to induce the adaptive responses. Extracts were prepared from these cultures and assayed for $\beta$-galactosidase activity. Neither superoxides nor $\mathrm{H}_{2} \mathrm{O}_{2}$ significantly affected the expression of either the MnSOD-encoding or the $\mathrm{Cu} / \mathrm{ZnSOD}$-encoding gene (Table 3 ). In agreement with an earlier report (Marchler et al., 1993), transcription of the CTT1 gene was shown to be inducible by $\mathrm{H}_{2} \mathrm{O}_{2}$, although the level of induction was low, only twofold (Table 3). Transcription of the CT $A 1$ gene was unaffected by exposure to oxidants. The lack of induction of the SOD2 and CTA1 genes in our assays is perhaps less surprising as cells grown in glucose express very little of the enzymes they encode because of glucose repression (Westerbeek-Marres et al., 1988; Ruis \& Hamilton, 1992).

The lack of inducibility of SOD1 gene expression by oxidants was surprising. There are several possible explanations for this. It is possible that transcription of the SOD1 gene is constitutive, as overexpression of SOD may be detrimental to cells; indeed, E. coli cells that overproduce the FeSOD are more susceptible to the toxic action of redox cyclers (Scott et al., 1987). It is also possible that the important functional elements of the SOD1 promoter lie further upstream of the DNA fragment used in the gene fusion construct. Another possibility is that aerobically grown cultures (as used in this study) already have maximally induced levels of the $\mathrm{Cu} / \mathrm{ZnSOD}$. These results suggest that although the $\mathrm{Cu} / \mathrm{ZnSOD}$ is an important enzyme in countering the toxicity of superoxide anions, it is not an inducible part of the superoxide adaptive stress response.

\section{Pretreatment of cells with menadione also induces the $\mathrm{H}_{2} \mathrm{O}_{2}$ adaptive stress response}

The action of SOD results in the production of $\mathrm{H}_{2} \mathrm{O}_{2}$, and it therefore seemed likely that treatment of cells with $1 \mathrm{mM}$ menadione could also lead to the induction of the $\mathrm{H}_{2} \mathrm{O}_{2}$ adaptive stress response as a result of the dismutation of superoxide anions. Indeed, previous work determined that treatment of yeast cells with menadione results in cross-protection against $\mathrm{H}_{2} \mathrm{O}_{2}$ (Jamieson, 1992). In order to test this idea we looked at the expression of the $\mathrm{H}_{2} \mathrm{O}_{2}$-responsive TRX2 gene. Transcription of this gene has been shown to be induced by the presence of $\mathrm{H}_{2} \mathrm{O}_{2}$ (Kuge \& Jones, 1994). Transformants of S150-2B carrying the $T R X 2$ : lac $Z$ gene fusion were grown to 


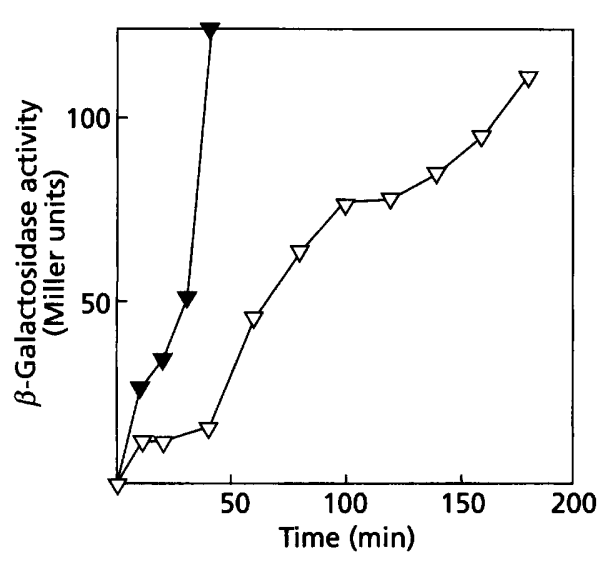

Fig. 4. Time course of induction of TRX2 gene expression by oxidants. Cultures of S150-2B transformed with pyTRX2::lacZ were grown aerobically to early exponential phase $\left(O D_{600}=0.1\right)$ in SD medium and then exposed to either $0.4 \mathrm{mM} \mathrm{H}_{2} \mathrm{O}_{2}(\nabla)$ or $1 \mathrm{mM}$ menadione $(\nabla)$. At various time intervals after addition of oxidant aliquots of the cultures were assayed for $\beta$ galactosidase activity (Miller units) (Guarente, 1983). Values represent the means of duplicate experiments.

early exponential phase, cultures were treated with adaptive levels of either $\mathrm{H}_{2} \mathrm{O}_{2}$ or menadione and $\beta$ galactosidase activity was measured at various times after addition of the oxidants. Induction of TRX2 gene expression by menadione proceeded more slowly than that observed with $\mathrm{H}_{2} \mathrm{O}_{2}$, suggesting that exposure to menadione produces $\mathrm{H}_{2} \mathrm{O}_{2}$ by an indirect route (Fig. 4). In addition to the slower induction of expression, the maximal level of expression is lower than that seen after $\mathrm{H}_{2} \mathrm{O}_{2}$ treatment. This delay in expression is not observed with those proteins which can be induced by both $\mathrm{H}_{2} \mathrm{O}_{2}$ and menadione (Fig. 3; Table 2), which are clearly apparent within $1 \mathrm{~h}$. This apparent discrepancy could be explained by the slower translation of the $116 \mathrm{kDa} \beta$ galactosidase protein (under oxidative stress conditions) compared to that of the $11.2 \mathrm{kDa}$ TRX2 protein. A more likely explanation would be to suggest that some proteins are genuinely induced by both types of oxidative stress, and possibly by other forms of stress, for example those encoding HSP12 and 26. Clarification of these ideas awaits identification and characterization of the induced proteins and their role in protection against stress.

\section{ACKNOWLEDGEMENTS}

We thank Drs S. Kuge and N. Jones for their provision of the $T R X 2:: l a c Z$ gene fusion and Dr E. Craig for the provision of the $S S A 1$ promoter fusion. We are grateful to Drs E. Ellis and $J$. Hayes for their suggestions and critical reading of the manuscript. This work was supported by a grant from the Wellcome Trust.

\section{REFERENCES}

Baggioloini, M. \& Thelen, M. (1991). In Oxidative Stress: Oxidants and Antioxidants, pp. 399-420. Edited by H. Sies. London: Academic Press.
Bermingham-McDonogh, O., Gralla, E. B. \& Valentine, J. S. (1988). The copper,zinc-superoxide dismutase gene of Saccharomyces cerevisiae: cloning, sequencing, and biological activity. Proc Natl Acad Sci US A 85, 4789-4793.

Bonneaud, N., Ozier-Kalogeropoulos, O., Li, G., Labouesse, M., Minivielle-Sebastia, L. \& Lacroute, F. (1991). A family of low and high copy replicative, integrative and single-stranded $S$. cerevisiae $/ E$. coli shuttle vectors. Yeast 7, 609-615.

Collinson, L. P. \& Dawes, I. W. (1992). Inducibility of the response of yeast cells to peroxide stress. J Gen Microbiol 138, 329-335.

Demple, B. (1991). Regulation of bacterial oxidative stress genes. Annu Rev Genet 25, 315-337.

Demple, B. \& Amabile-Cuevas, C. F. (1991). Redox redux: the control of oxidative stress responses. Cell 67, 837-839.

Dowds, B. C. A., Murphy, P., McConnell, D. J. \& Devine, K. M. (1987). Relationship among oxidative stress, growth cycle, and sporulation in Bacillus subtilis. J Bacteriol 169, 5771-5775.

Flattery-O'Brien, J., Collinson, L. P. \& Dawes, I. W. (1993). Saccharomyces cerevisiae has an inducible response to menadione which differs from that to hydrogen peroxide. J Gen Micrabiol 139, 501-507.

Guarente, L. (1983). Yeast promoters and lac $Z$ fusions designed to study expression of cloned genes in yeast. Methods Enzymol 101, 181-191.

Guidot, D. M., McCord, J. M., Wright, R. M. \& Repine, J. E. (1993). Absence of electron transport (Rho ${ }^{0}$ state) restores growth of a manganese-superoxide dismutase-deficient Sacharomyces cerevisiae in hyperoxia. $J$ Biol Chem 268, 26699-26703.

Greenberg, J. T. \& Demple, B. (1989). A global response induced in Escherichia coli by redox-cycling agents overlaps with that induced by peroxide stress. J Bacteriol 171, 3933-3939.

Halliwell, B. \& Gutteridge, J. M. C. (1984). Oxygen-toxicity, oxygen radicals, transition-metals and disease. Biochem J 219, 1-14.

Ito, H., Fukuda, Y., Murata, K. \& Kimura, A. (1983). Transformation of intact yeast cells treated with alkali cations. J Bacteriol 153 , 163-168.

Jamieson, D. J. (1992). Saccharomyces cerevisiae has distinct adaptive responses to both hydrogen peroxide and menadione. $J$ Bacteriol 174, 6678-6681.

Kuge, S. \& Jones, N. (1994). YAP1 dependent activation of TRX2 is essential for the response of Saccbaromyces cerevisiae to oxidative stress by hydroperoxides. EMBO J 13, 655-664.

Laemmli, U. K. (1970). Cleavage of structural proteins during the assembly of the head of bacteriophage T4. Nature 227, 680-685.

Lee, J.-S., Hah, Y.-C. \& Roe, J.-H. (1993). The induction of oxidative enzymes in Streptomyces coelicolor upon hydrogen peroxide treatment. $J$ Gen Microbiol 139, 1013-1018.

Marchler, G., Schuller, C., Adam, G. \& Ruis, H. (1993). A Saccharomyces cerevisiae UAS element controlled by protein kinase A activates transcription in response to a variety of stress conditions. EMBO J 12, 1997-2003.

McCord, J. M. \& Fridovich, I. (1969). Superoxide dismutase. An enzymic function for erythrocuprein (hemocuprein). $J$ Biol Chem 244, 6049-6055.

Petko, L. \& Lindquist, S. (1986). HSP26 is not required for growth at high temperatures, nor for thermotolerance, spore development, or germination. Cell 45, 885-894.

Rose, M. D., Winston, F. \& Hieter, P. (1990). Methods in Yeast Genetics. Cold Spring Harbor, NY : Cold Spring Harbor Laboratory.

Rothstein, R. J. (1983). One-step gene disruption in yeast. Methods Enzymol 101, 202-211. 
Ruis, H. \& Hamilton, B. (1992). Regulation of yeast catalase genes. In Molecular Biology of Free Radical Scavenging Systems, pp. 153-172. Cold Spring Harbor, NY: Cold Spring Harbor Laboratory.

Scott, M. D., Meshnick, S. R. \& Eaton, J. W. (1987). Superoxide dismutase-rich bacteria. $J$ Biol Chem 262, 3640-3645.

Sherman, F., Fink, G. R. \& Hicks, J. B. (1982). Methods in Yeast Genetics. Cold Spring Harbor, NY : Cold Spring Harbor Laboratory.

Slater, M. R. \& Craig, E. A. (1987). Transcriptional regulation of an hsp 70 heat shock gene in the yeast Saccharomyces cerevisiae. Mol Cell Biol 7, 1906-1916.

Storz, G., Christman, M. F., Sies, H. \& Ames, B. N. (1987). Spontaneous mutagenesis and oxidative damage to DNA in Salmonella typhimurium. Proc Natl Acad Sci US A 84, 8917-8921.

Storz, G., Tartaglia, L. A., Farr, S. B. \& Ames, B. N. (1990). Bacterial defenses against oxidative stress. Trends Genet 6, 363-368.
Van Loon, A. P. G. M., Pesold-Hurt, B. \& Schatz, G. (1986). A yeast mutant lacking mitochondrial manganese-superoxide dismutase is hypersensitive to oxygen. Proc Natl Acad Sci US A 83, 3820-3824.

Varela, J. C. S., Van-Beekvelt, C., Planta, R. J. \& Mager, W. H. (1992). Osmostress-induced changes in yeast gene expression. Mol Microbiol 6, 2183-2190.

Weesterbeek-Marres, C. A. M., Moore, M. M. \& Autor, A.P. (1988). Regulation of manganese superoxide dismutase in Saccharomyces cerevisiae. Eur J Biochem. 174, 611-620.

Wolff, S. P., Garner, A. \& Dean, R. T. (1986). Free radicals, lipids and protein degradation. Trends Biochem Sci 11, 27-31.

Received 21 June 1994; revised 15 August 1994; accepted 7 September 1994. 